\title{
Synthesis of Luminescent Squaramide Monoesters: Cytotoxicity and Cell Imaging Studies in HeLa Cells
}

\author{
Vanesa Fernández-Moreira, ${ }^{a}$ Juan V. Alegre-Requena,${ }^{a, b}$ Raquel P. Herrera, ${ }^{* a}$ \\ Isabel Marzo ${ }^{c}$ and M. Concepción Gimeno*c
}

\begin{abstract}
Novel luminescent squaramide monoesters functionalised with different fluorophore groups have been synthesised and explored in cell imaging for the first time. Cytotoxicity studies performed in HeLa cervical cancer cells revealed high activity for some of these novel structures, pointing out the importance of the fluorescent fragment in the efficiency of these promising anticancer agents. In addition, fluorescence cell microscopy revealed the different biodistribution behaviour depending on the fluorescent moiety, and the possibility of nuclear localisation of chiral non planar squaramide monoesters.
\end{abstract}

\section{Introduction}

In the last decade, squaramides have received a special attention since they exhibit unique promising properties that make them appealing for many different areas of research, such as medicine, ${ }^{1}$ catalysis ${ }^{2}$ and synthesis. ${ }^{3}$

One of the most important features that these scaffolds display is their ability for selectively binding through cooperative hydrogen bonds. This interesting property is being extensively investigated in the area of asymmetric organocatalysis, ${ }^{2}$ since the pioneering work reported by Rawal and co-workers in 2008. ${ }^{4}$ Thus, the use of squaramides as excellent hydrogen bond donor catalysts has been experiencing an impressive growth. Beyond their application in catalysis, the squaramides capacity as receptors for molecular recognition ${ }^{5}$ is being actually explored in medicinal chemistry. ${ }^{6}$

The facility of different active compounds to penetrate in the cells could be decisive for the effectiveness of drug delivery. However, for that purpose, many times these compounds must be transported by using additional carriers, which often exhibit diverse toxicity levels with the corresponding cell damage. In contrast, other promising drug candidates can effectively cross the cell membrane by the formation of hydrogen bond and electrostatic interactions between the compound and a cell membrane receptor or the cell membrane surface.

The squaramides have an interesting dual behaviour, as they are able to act as good hydrogen bond donor and acceptors, which made them suitable for both cation and anion recognition, respectively. There are some examples of receptors based on the squaramide motif, i.e. Costa's group has provided evidence that squaramide-based molecules are able of binding both cations $^{7}$ and anions, ${ }^{8}$ by means of different computational and experimental methods. More recently, Taylor, ${ }^{9}$ Fabbrizzi, ${ }^{10}$ and co-workers among other research groups ${ }^{11}$ have employed squaramide-based receptors for the recognition of various anions.

Moreover, squaramide motifs have been the focus of an increased interest in medicine being considered as promising candidates for drug design. ${ }^{1,12}$ However, to the best of our knowledge the study of squaramide monoesters as cytotoxic agents or for cell imaging has been overlooked in the literature so far, and no examples as potential anticancer agents have been previously reported. In this respect, we envisioned that the ability of squaramide monoesters to generate hydrogen bonds and electrostatic interactions could be an interesting option to design specific recognition systems, for its consequent internalisation into the cell. All these, together with the interest of searching for new antitumor agents, encouraged us to explore the antitumor activity of a variety of squaramide monoesters in HeLa cells. Herein, we report on the synthesis of new luminescent squaramide monoesters and a squaramide derivative with anticancer activity together with their exploration in fluorescence cell microscopy

\section{Results and discussion}

Taking into the account all the unique properties of squaramides and the lack of background of squaramide monoesters, we hypothesised that these species could form 
plausible interactions or covalent bonds with internal amine groups belonging to biological molecules in the cells, generating the resulting squaramide, or could be anchored by acidic organelles to help in the internalisation into the cells (Scheme 1).

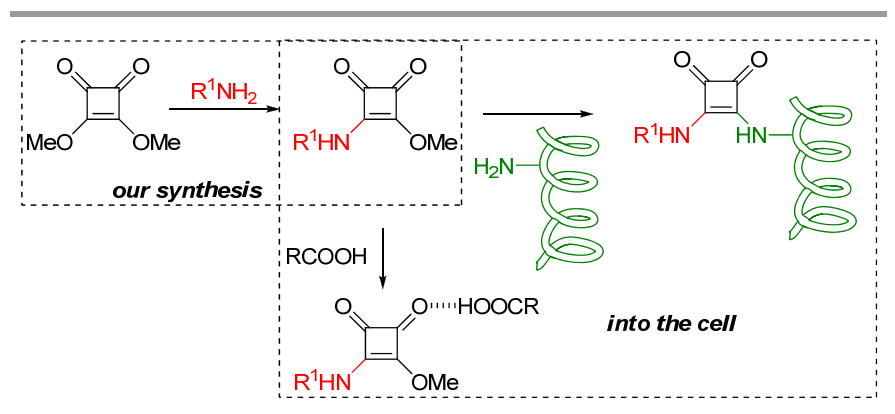

Scheme 1 Synthesis of squaramide monoesters and possible reaction/interaction of squaramide monoesters into the cells. (green helix: biological material containing a amine group)

Consequently, we started preparing a battery of squaramide monoesters following the optimised reaction conditions recently reported by us. ${ }^{13}$ In this manner, squaramide monoesters 1-7 and the squaramide 8 containing several fluorophore groups were synthesised, with the aim to make them useful for cell imaging studies (Figure 1).<smiles>COc1c(Nc2ccc(-c3ccc(Nc4c(OC)c(=O)c4=O)cc3)cc2)c(=O)c1=O</smiles>

1

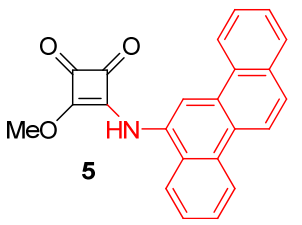

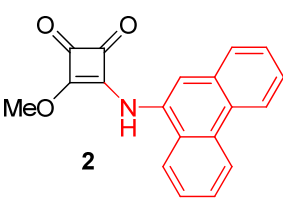
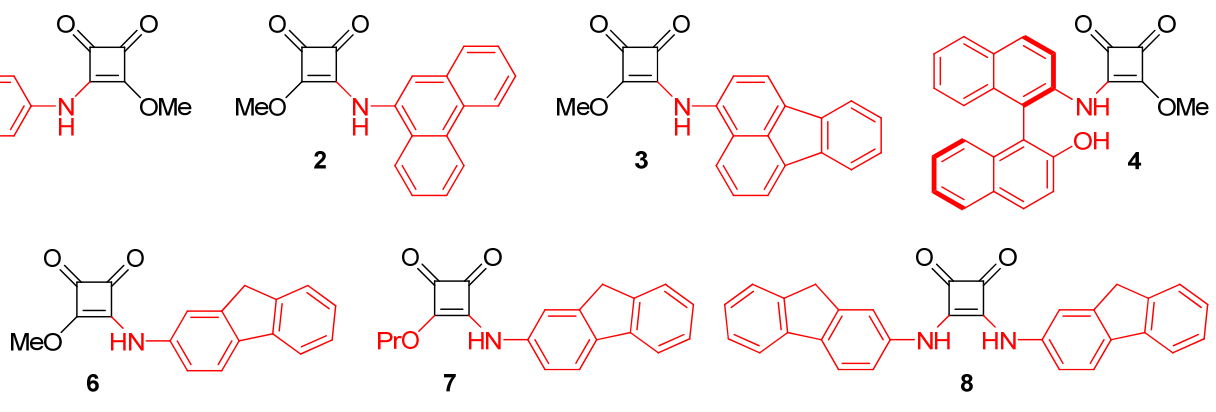

(-

8

Fig. 1 Model squaramide monoester and squaramide structures 1-8 tested.

With these model structures, the photophysical and biological properties of all these new compounds were examined. UV-visible absorption, emission and excitation spectra of compounds 1-8 were recorded in a dimethylsulfoxide solution at $298 \mathrm{~K}$ and the most significant data are collected in Table 1.

Table 1 Absorption bands, excitation and emission values $\left(1 \cdot 10^{-5} \mathrm{M}\right.$, DMSO, $298 \mathrm{~K})$ and quantum yields $\left(2 \cdot 10^{-5} \mathrm{M}, \mathrm{DMSO}, 298 \mathrm{~K}\right)$ for compounds $\mathbf{1 - 8}$.

\begin{tabular}{|c|c|c|c|c|}
\hline & $\lambda_{\max } / \mathrm{nm}\left(\varepsilon / \mathrm{dm}^{3} \mathrm{~mol}^{-1} \mathrm{~cm}^{-1}\right)$ & $\lambda_{\text {exc }} / \mathbf{n m}$ & $\lambda_{\mathrm{em}} / \mathbf{n m}$ & $\Phi$ \\
\hline 1 & $292(22500)$ sh, 353 (54000) & 450 & 515 & 0.2 \\
\hline 2 & 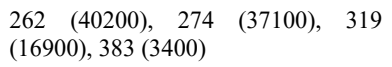 & 414 & 474 & 27.9 \\
\hline 3 & $\begin{array}{l}259(25100), \quad 337 \quad(14800), \quad 483 \\
(14000)\end{array}$ & 514 & 591 & 45.7 \\
\hline 4 & $\begin{array}{l}283 \quad(27800), \quad 318 \quad(21500), \\
(18500) \mathrm{sh}, 378(7020) \mathrm{sh}\end{array}$ & 375 & 490 & 0.7 \\
\hline 5 & $266(76200), 348(18000), 416(3300)$ & 490 & 616 & 0.6 \\
\hline 6 & 334 (32300), 394 (5400) sh & 440 & 508 & 0.5 \\
\hline 7 & 280 (14900) sh, 332 (30000), 434 & 457 & 525 & 2.3 \\
\hline
\end{tabular}

(11000)

$8 \quad 280(32600), 374(88900), 430(7600) \quad 434 \quad 525 \quad 7.3$

$\mathrm{sh}=$ shoulder

Photophysical properties of the specific fluorophores, benzidine, 9-aminophenanthrene, 3-aminofluoranthene, NOBIN, 6-aminochrysene and 2-aminofluorene were also analyzed for comparison purposes (Figures S1 and S2).

Squaramide monoesters 1-7 and the squaramide 8 had similar absorption spectra pattern to that of their correspondent fluorophores. Specifically compounds $\mathbf{2}, \mathbf{4}$ and $\mathbf{5}$ presented a $\pi$ $\rightarrow \pi^{*}$ transition at high energy, $<300 \mathrm{~nm}$, followed by a less intense $\mathrm{n} \rightarrow \pi^{*}$ transition and going in line with the UV-vis spectra of their fluorophores. In the case of compounds $\mathbf{1}, \mathbf{3}, \mathbf{6}$, $\mathbf{7}$ and $\mathbf{8}$, there is a clear red shift in the absorption bands in comparison with that of the free fluorophore. Probably, the linearity between the squarate skeleton with that of the fluorophores enables an increase of the electronic delocalisation between both fragments, and thus, a stabilisation of the LUMO orbitals. Furthermore, compound 5, 7 and $\mathbf{8}$ showed an additional absorption band at lower energies, $416 \mathrm{~nm}, 434$ and 430 , respectively, that could suggest the deprotonation of the $\mathrm{NH}$ group by the DMSO used as solvent. A similar effect has already been observed by Taylor and co-workers for $\mathrm{N}, \mathrm{N}$ - 
diarylsquaramides, when changing the solvent of the UVvisible analysis from $\mathrm{CH}_{3} \mathrm{CN}$ to DMSO a new absorption band appeared over $400 \mathrm{~nm} .{ }^{9 \mathrm{a}}$

Luminescence spectra of all the synthesised species showed a broad emission band between 475 and $615 \mathrm{~nm}$ which was tentatively attributed to IL transition processes among the fluorophores and the squaramide (Figure 2).

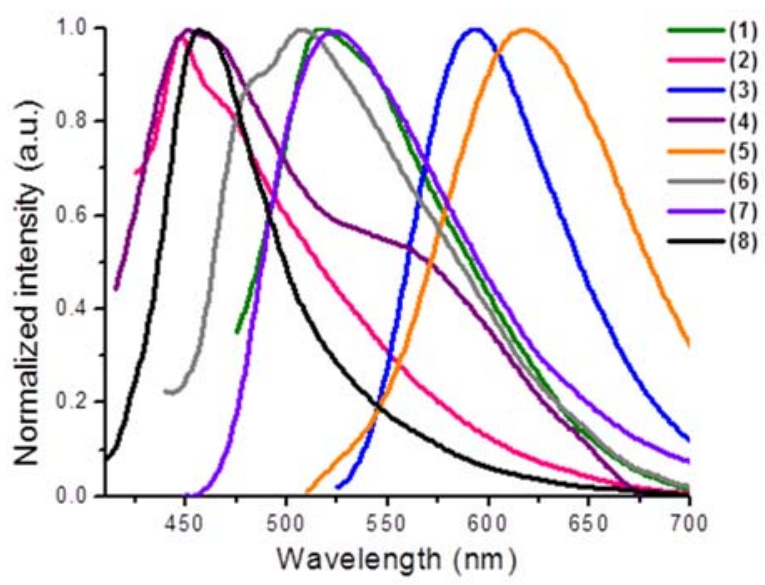

Fig. 2 Normalized emission spectra of compounds $\mathbf{1 - 8}$ recorded in DMSO solution at $298 \mathrm{~K}$.

In concordance with the UV-vis results, compounds $\mathbf{1 , 3 , 6}$, $\mathbf{7}$ and $\mathbf{8}$ presented a high red shift of the emission maxima in comparison with that observed for their fluorophores. Conversely, compound $\mathbf{5}$ also presented a red shifted emission of c.a. $200 \mathrm{~nm}$ that contrasted with the similarity of the absorption spectra of $\mathbf{5}$ and its fluorophore, indicating the high influence of the substituents on the emissive properties. ${ }^{14}$ Even though all of them displayed a highly intense luminescence, compound $\mathbf{8}$ stands out as the most emissive species, possibly because of the presence of two fluorophores within its structure. Stokes shifts vary from 25 to $150 \mathrm{~nm}$, which denotes a fluorescence nature for the emission.

The quantum yields for compounds 1-8 have been measured in DMSO solution. Significant values were obtained for compounds 2 and 3 with quantum yields of 25.9 and $45.7 \%$, respectively, and a smaller value of $7.5 \%$ for $\mathbf{8}$. Considerably lower values, $<1 \%$, were obtained for the rest of derivatives.

In view of the excellent emission properties of compounds 1-8, a series of experiments were undertaken to test their cytotoxic activity and viability as specific cell imaging agents in human HeLa cervical cancer cells. Cytotoxic studies were performed by a MTT assay and revealed that compounds 1, 3 and 6-8 possess the higher cytotoxic activity (Table 2). These compounds correspond to the benzidine, aminofluoranthene, and aminofluorene derivatives, and all of them are known to be useful platforms for designing antitumoral compounds. ${ }^{15}$ The aminochrysene species $\mathbf{5}$ has a moderate cytotoxic activity of $25.3 \mu \mathrm{M}$. These results suggest that the fluorophores which contain a cyclopentadiene moiety are the most active species, followed by the benzidine fluorophore which has two connected phenyl units, whereas those with fused phenyl rings are less cytotoxic.

\begin{tabular}{|c|c|c|c|c|}
\hline Comp. & 1 & 2 & 3 & 4 \\
\hline $\mathrm{IC}_{50}$ & $2.25 \pm 1.1$ & $115.6 \pm 13.9$ & $0.88 \pm 0.22$ & $46.7 \pm 0.3$ \\
\hline Comp. & 5 & 6 & 7 & 8 \\
\hline $\mathrm{IC}_{50}$ & $25.3 \pm 11.4$ & $1.02 \pm 0.07$ & $1.17 \pm 0.07$ & $1.18 \pm 0.23$ \\
\hline
\end{tabular}

On the basis of the luminescence and cytotoxic activity results of compounds 1-8, fluorescence confocal microscopy was used with selected species to assess their suitability as cell imaging agents. Among them, species 1, 3, and 6-8 were discarded for this analysis because they displayed high cytotoxicity, and some of them low solubility in the buffer media, features to avoid in the design of bioprobes for cell imaging application. Therefore, selected squaramide monoesters 2, 4 and 5 were incubated with HeLa cells using loading concentrations below their $\mathrm{IC}_{50}$ to avoid cellular death and the subsequent possible changes of localisation. ${ }^{16}$ A known lysosomal co-staining fluorescent dye, LisoTracker Red DND-99, was used as internal standard to ascertain the localisation. Confocal fluorescent images were taken after excitation at either $405 \mathrm{~nm}$ or $473 \mathrm{~nm}$ and $578 \mathrm{~nm}$. When the cells were irradiated at $405 \mathrm{~nm}$ or 473 $\mathrm{nm}$, only the emission from the synthesised compounds was observed, whereas exciting at $578 \mathrm{~nm}$, the displayed emission would be that of the commercial fluorescent dye, which is localised in the lysosomes. Specifically, the laser of $405 \mathrm{~nm}$ was used to excite $\mathbf{2}$ and $\mathbf{4}$, and species $\mathbf{5}$ was visualised upon excitation at $473 \mathrm{~nm}$, going in line with the different photophysical behaviour (Table 1). Superimposition of the images obtained upon excitation at either $405 \mathrm{~nm}$ or 473 with that obtained upon excitation at $578 \mathrm{~nm}$ for the internal standard gave crucial information to elucidate the possible localisation pattern (Figures 3 and 4). 

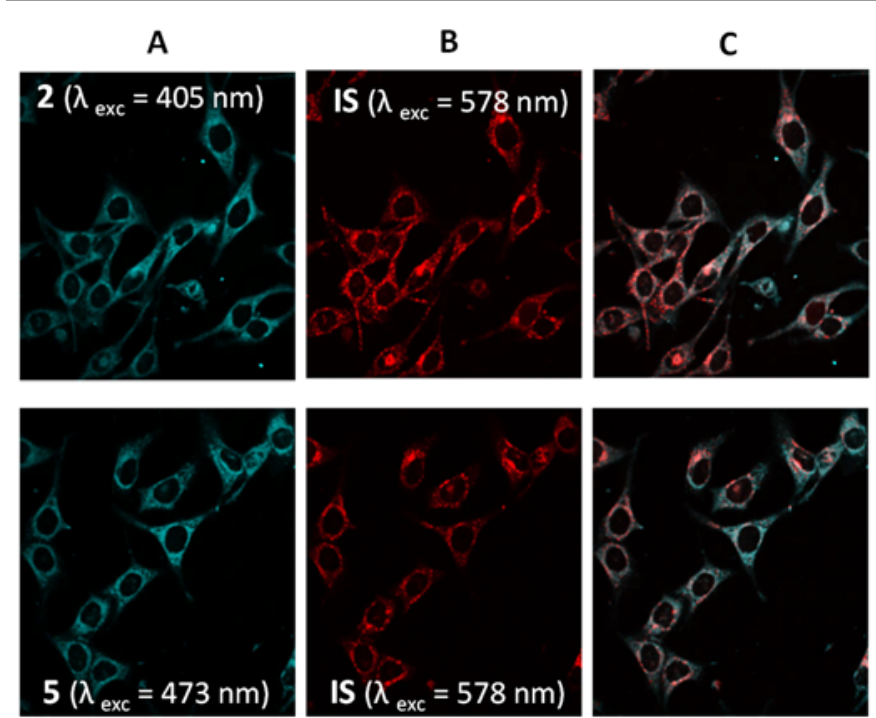

Fig. 3 Fluorescence microscopy images of HeLa cells incubated with compound 2 and 5 at a concentration of $50 \mu \mathrm{M}$ and $12.5 \mu \mathrm{M}$ respectively for $12 \mathrm{~h}$ at $37^{\circ} \mathrm{C}$; (A) Images upon excitation at either 405 or $473 \mathrm{~nm}$; (B) Images upon excitation at $578 \mathrm{~nm}$ for visualizing the internal standard (IS); (C) Superimposed image of (A) and (B).

Hence, both 2 and 5 showed an emission coming from the cytoplasm area and a more specific granulated accumulation in the perinuclear region. Remarkably, the superimposition image (Figure 3, C), showed that both species, compounds 2 and $\mathbf{5}$ seemed to have some accumulation in the same organelles than the internal standard i.e., the LisoTracker Red DND-99 that is retained in the lisosomes. Consequently, it could be reasonable to think that $\mathbf{2}$ and $\mathbf{5}$ could be localised in acidic vesicles such as endosomes as well as in lysosomes. Specifically, late endosomes bear an acidic environment $(\mathrm{pH}=4.7)$ and they move towards the perinuclear region after their formation. They arise from the maturation of early endosomes, which in turn are formed by an endocytosis process and, therefore, pointing out to an energy-dependent pathway as the internalisation process. ${ }^{17}$

Costa, Rotger and co-workers report in the examination of fluorescent cyclosquaramides ${ }^{6 \mathrm{~b}}$ that internalization of the probe into the cell takes place through endocytotic receptor-mediated mechanisms and remains sequestered in late endosomes. The authors attributed this to the strong affinity of cyclosquaramides for anionic phosphate compounds present on the cell membrane. In the present case, compounds $\mathbf{2}$ and $\mathbf{5}$ have the also the ability to form covalent bonds with biological molecules bearing amine groups in the cell membrane, which could be the pathway to enter the cell.

To shed more light on this energy-dependent pathway and the absence of passive transport the evaluation of the uptake of compound 5 in HeLa cell line, at a concentration of $100 \mu \mathrm{M}$ for $2 \mathrm{~h}$ at $37^{\circ} \mathrm{C}$ and at $4{ }^{\circ} \mathrm{C}$, was evaluated via flow cytometry (see Fig, $\mathrm{S}$ in Supporting Information). Under these conditions, the uptake was significantly reduced at $4{ }^{\circ} \mathrm{C}$ compared to that observed at $37{ }^{\circ} \mathrm{C}$. Although, undoubtedly this uptake is temperature dependent, the fact that no uptake is observed at 4
${ }^{\circ} \mathrm{C}$, together with the lysosomal localization obtained for this compound in HeLa cells, suggest that internalization is an energy dependent process, indicating that the mechanism might be receptor-mediated endocytotic process.

In addition, negligible emission from the nucleus itself indicates that both compounds remained only in the outer part. In contrast, when the same experiment was performed with $\mathbf{4}$, a completely different bio-distribution pattern was observed (Figure 4)

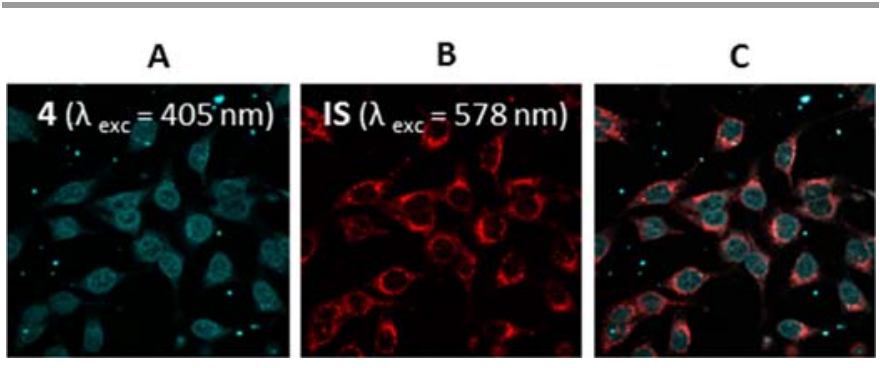

Fig. 4 Fluorescence microscopy images of HeLa cells incubated with compound 4 at a concentration of $35 \mu \mathrm{M}$ for $12 \mathrm{~h}$ at $37^{\circ} \mathrm{C}$; (A) Image upon excitation at 405 $\mathrm{nm}$; (B) Image upon excitation at either $578 \mathrm{~nm}$; (C) Superimposed image of (A) and (B).

Interestingly, compound $\mathbf{4}$ entered the cell, and accumulated in the nuclear region. A closer look revealed that the nuclear distribution was not homogenous, thus, presenting a granulated emission (Figure $4, \mathbf{C}$ ). The fact that $\mathbf{4}$ was able to permeate the nucleus indicates that either its acidic character is different from that of $\mathbf{2}$ and $\mathbf{5}$ and, consequently, they can escape from the internalisation in the endosomes and lysosomes, or that the cellular internalisation mechanism did not occur via an endocytotic process. An additional factor to take into account for the different biodistribution is the chirality and nonplanarity of the fluorophore fragment. Previous work published by Seitz and co-workers highlights that even though the typical base surrogates are planar to help the $\pi$-stacking as well as hydrophobic interactions with the DNA bases, it is possible to intercalate non-planar aromatic structures such as binaphthyl derivatives. ${ }^{18}$ They assume that the torsional flexibility of the binaphthyl hinge is assisting the staking interactions to take place at the interior and exterior of the DNA duplex. Considering the chemical similarity between binaphthyl and NOBIN, the fluorophore appended in compound 4 , it might be reasonable to think that a similar process is occurring in this case. In addition, the chirality of the probe may lead also to specific DNA binding and chiral recognition, a key feature for designing selective bioprobes. ${ }^{19}$

\section{Conclusions}

In summary, novel luminescent squaramide monoesters have been explored as bioactive agents and in cell imaging for the first time. Cytotoxicity studies performed in $\mathrm{HeLa}$ cells revealed a high activity for some of these species, where the selection of the fluorescent fragment seems to be decisive for 
the efficiency of these promising anticancer agents in HeLa cells. Fluorophores containing the cyclopentadiene unit or with not fused phenyl rings are the most active. In addition, fluorescence cell microscopy pointed out the different biodistribution behaviour depending on the fluorescent moiety, and both lysosomal and nuclear localisation has been observed, which highlights the possibility for chiral and non-planar bioprobes, as in the case of complex 4, which accumulates in the nuclear area. Since the squaramide functionality provides a way to increase the transport ability of a receptor without significantly increasing the lipophilicity, it offers an ideal platform for designing future anion transporters. More complex squaramide-containing transporters are currently being investigated in our laboratory and will be published in due course.

\section{Experimental Section}

General experimental methods and instrumentation.

Purification of reaction products was carried out either by filtration or by flash chromatography using silica-gel (0.063$0.200 \mathrm{~mm})$. Analytical thin layer chromatography was performed on $0.25 \mathrm{~mm}$ silica gel $60-\mathrm{F}$ plates. ESI ionisation method and mass analyser type MicroTof-Q were used for the ESI measurements. ${ }^{1} \mathrm{H}$ and ${ }^{13} \mathrm{C}\left\{{ }^{1} \mathrm{H}\right\}$-APT NMR were recorded at room temperature on a BRUKER AVANCE 400 spectrometer $\left({ }^{1} \mathrm{H}, 400 \mathrm{MHz} ;{ }^{13} \mathrm{C}, 100.6 \mathrm{MHz}\right)$ or on a BRUKER AVANCE II 300 spectrometer $\left({ }^{1} \mathrm{H}, 300 \mathrm{MHz} ;{ }^{13} \mathrm{C}\right.$, $75.5 \mathrm{MHz}$ ) in DMSO- $d_{6}$ as solvent. Chemical shifts were reported in the $\delta$ scale relative to residual DMSO $(2.50 \mathrm{ppm})$ for ${ }^{1} \mathrm{H}$ NMR and to the central line of DMSO (39.43 ppm) for ${ }^{13} \mathrm{C}$ NMR. Room temperature steady-state emission and excitation spectra were recorded with a Jobin-Yvon-Horiba fluorolog FL3-11 spectrometer fitted with a JY TBX picosecond detection module. UV/vis spectra were recorded with a $1 \mathrm{~cm}$ quartz cells on an Evolution 600 spectrophotometer. The quantum yields were measured in a Hamamatsu Photonics KK in DMSO solution.

\section{Representative procedure for synthesis of squaramide} monoesters 1-7 and squaramide 8

To a mixture of 3,4-dimethoxy-3-cyclobutene-1,2-dione $(0.2$ $\mathrm{mmol})$ in $\mathrm{MeOH}(0.5 \mathrm{~mL})$, the corresponding amine $(0.2 \mathrm{mmol})$ was added in one portion at room temperature. After a reaction time, the mixture was cooled in the freezer $(30 \mathrm{~min})$ and the product was purified by filtration and washed with cold $\mathrm{MeOH}$ $(2 \mathrm{~mL})$ or by column chromatography when necessary. Yields are reported below and pure compounds were obtained as stable solids.

\section{4,4'-([1,1'-Biphenyl]-4,4'-diylbis(azanediyl))bis(3- \\ methoxycyclobut-3-ene-1,2-dione) (1)}

Following the general procedure, compound $\mathbf{1}$ was obtained after $64 \mathrm{~h}$ of reaction at room temperature as a yellow solid in $75 \%$ yield $(61 \mathrm{mg})$. M.p. $>260{ }^{\circ} \mathrm{C}$ Decomp. ${ }^{1} \mathrm{H}$ NMR $(300$ $\left.\mathrm{MHz}, \mathrm{DMSO}-d_{6}, 60{ }^{\circ} \mathrm{C}\right) \delta 10.84(\mathrm{~s}, 2 \mathrm{H}), 7.67(\mathrm{~d}, J=8.6 \mathrm{~Hz}$,
4H), 7.44 (d, $J=7.6 \mathrm{~Hz}, 4 \mathrm{H}), 4.41(\mathrm{~s}, 6 \mathrm{H}) .{ }^{13} \mathrm{C}-\mathrm{APT}$ NMR $(75$ $\left.\mathrm{MHz}, \mathrm{DMSO}-d_{6}, 60^{\circ} \mathrm{C}\right) \delta 136.9$ (2C), 134.7 (2C), 126.5 (4C), 119.7 (4C), 60.2 (2C). IR (KBr film) $\left(\mathrm{cm}^{-1}\right) \vee 3250,3192$, 3095, 2923, 2853, 1797, 1706, 1616, 1569, 1514, 1456, 1392, 1377, 1080, 926, 846, 733, 457. MS (ESI+) 405.2 [M + H]. HRMS (ESI+) calcd for $\mathrm{C}_{22} \mathrm{H}_{16} \mathrm{~N}_{2} \mathrm{NaO}_{6}$ 427.0901; found $427.0896[\mathrm{M}+\mathrm{Na}]$.

\section{3-Methoxy-4-(phenanthren-9-ylamino)cyclobut-3-ene-1,2-} dione (2)

Following the general procedure, compound $\mathbf{2}$ was obtained after $64 \mathrm{~h}$ of reaction at room temperature as a white solid in $58 \%$ yield (35.5 mg). M.p. $188-190{ }^{\circ} \mathrm{C} .{ }^{1} \mathrm{H}$ NMR (400 MHz, DMSO- $\left.d_{6}\right) \delta 11.03(\mathrm{~s}, 1 \mathrm{H}), 8.93-8.88(\mathrm{~m}, 1 \mathrm{H}), 8.86-8.81(\mathrm{~m}$, $1 \mathrm{H}), 8.18(\mathrm{dd}, J=8.0,1.4 \mathrm{~Hz}, 1 \mathrm{H}), 7.95(\mathrm{dd}, J=7.6,1.7 \mathrm{~Hz}$, $1 \mathrm{H}), 7.82-7.63(\mathrm{~m}, 5 \mathrm{H}), 4.30(\mathrm{~s}, 3 \mathrm{H}) .{ }^{13} \mathrm{C}-\mathrm{APT}$ NMR $(100$ MHz, DMSO-d6) $\delta 188.6$ (1C), 184.7 (1C), 178.8 (1C), 171.2 (1C), 131.1 (1C), 130.9 (1C), 130.3 (1C), 128.5 (1C), 128.4 (1C), 127.4 (1C), 127.4 (1C), 127.1 (1C), 127.0 (1C), 126.8 (1C), 123.6 (1C), 123.3 (1C), 122.9 (1C), 121.1 (1C), 60.4 (1C). IR (KBr film) $\left(\mathrm{cm}^{-1}\right) v$ 3214, 2953, 2924, 2853, 1812, 1694, 1621, 1454, 1362, 1231, 936, 766, 749, 727, 420. MS $(\mathrm{ESI}+) 326.1[\mathrm{M}+\mathrm{Na}]$. HRMS (ESI+) calcd for $\mathrm{C}_{19} \mathrm{H}_{13} \mathrm{NNaO}_{3}$ 326.0788; found $326.0778[\mathrm{M}+\mathrm{Na}]$.

\section{3-(Fluoranthen-3-ylamino)-4-methoxycyclobut-3-ene-1,2- dione (3)}

Following the general procedure, compound 3 was obtained after $93 \mathrm{~h}$ of reaction at room temperature and purified by column chromatography, as a red solid in $49 \%$ yield (32.2 $\mathrm{mg}$ ). M.p. $>260{ }^{\circ} \mathrm{C}$ Decomp. ${ }^{1} \mathrm{H}$ NMR (400 MHz, DMSO-d $d_{6} \delta$ $11.24(\mathrm{~s}, 1 \mathrm{H}), 8.16(\mathrm{~d}, J=8.1 \mathrm{~Hz}, 2 \mathrm{H}), 8.11(\mathrm{~d}, J=7.5 \mathrm{~Hz}, 1 \mathrm{H})$, 8.06-8.01 (m, 2H), $7.74(\mathrm{dd}, J=8.2 \mathrm{~Hz}, J=7.1 \mathrm{~Hz}, 1 \mathrm{H}), 7.45$ $(\mathrm{d}, J=7.5 \mathrm{~Hz}, 1 \mathrm{H}), 7.44-7.39(\mathrm{~m}, 2 \mathrm{H}), 4.35$ (s, 3H). ${ }^{13} \mathrm{C}-\mathrm{APT}$ NMR (100 MHz, DMSO-d6) $\delta 188.2$ (1C), 184.8 (1C), 179.0 (1C), 170.3 (1C), 138.5 (1C), 138.1 (1C), 136.0 (1C), 133.5 (1C), 133.3 (1C), 131.8 (1C), 128.1 (1C), 127.9 (1C), 127.3 (1C), 123.8 (1C), 123.0 (1C), 121.9 (1C), 121.6 (1C), 121.5 (1C), 121.1 (1C), 120.9 (1C), 60.4 (1C). IR (KBr film) $\left(\mathrm{cm}^{-1}\right) v$ 3322, 3285, 2923, 2853, 1801, 1711, 1583, 1453, 1362, 1282, $1257,940,849,778,756,750,456 . \mathrm{MS}(\mathrm{ESI}+)$ 350.1 [M + $\mathrm{Na}$. HRMS (ESI+) calcd for $\mathrm{C}_{21} \mathrm{H}_{13} \mathrm{NNaO}_{3} 350.0788$; found $350.0780[\mathrm{M}+\mathrm{Na}]$.

\section{3-([(R)-2'-hydroxy-\{1,1'-binaphthalen $\}-2-y l]$ amino $)-4-$ methoxycyclobut-3-ene-1,2-dione (4)}

Following the general procedure, compound 4 was obtained after $120 \mathrm{~h}$ of reaction at room temperature and purified by column chromatography (Hex:EtOAc 7:3 to $3: 7$ ), as a yellow solid in $76 \%$ yield $(60 \mathrm{mg})$. M.p. $142-144{ }^{\circ} \mathrm{C}$. $[\alpha] \mathrm{D}^{24}=+152.7$ (c $\left.0.27, \mathrm{CHCl}_{3}\right) .{ }^{1} \mathrm{H} \mathrm{NMR}\left(400 \mathrm{MHz}, \mathrm{DMSO}-d_{6}\right) \delta 9.97$ (br s, $1 \mathrm{H}), 9.66$ (br s, 1H), 8.04 (d, $J=9.2 \mathrm{~Hz}, 1 \mathrm{H}), 8.01$ (d, $J=9.7$ $\mathrm{Hz}, 1 \mathrm{H}), 7.93(\mathrm{~d}, J=8.9 \mathrm{~Hz}, 1 \mathrm{H}), 7.88(\mathrm{~d}, J=8.1 \mathrm{~Hz}, 1 \mathrm{H}), 7.59$ $(\mathrm{d}, J=8.7 \mathrm{~Hz}, 1 \mathrm{H}), 7.50-7.44(\mathrm{~m}, 1 \mathrm{H}), 7.35(\mathrm{~d}, J=8.9 \mathrm{~Hz}, 1 \mathrm{H})$, 7.33-7.23 (m, 2H), 7.19-7.14 (m, 1H), $7.06(\mathrm{~d}, J=8.5 \mathrm{~Hz}, 1 \mathrm{H})$, $6.84(\mathrm{~d}, J=8.3 \mathrm{~Hz}, 1 \mathrm{H}), 4.23(\mathrm{~s}, 3 \mathrm{H}) .{ }^{13} \mathrm{C}-\mathrm{APT}$ NMR $(100$ 
MHz, DMSO- $\left.d_{6}\right) \delta 188.3$ (1C), 183.9 (1C), 178.3 (1C), 170.5 (1C), 153.2 (1C), 134.1 (1C), 133.6 (1C), 132.3 (1C), 131.5 (1C), 129.7 (1C), 128.0 (1C), 127.9 (1C), 127.9 (1C), 126.6 (1C), 126.4 (1C), 126.1 (1C), 125.7 (1C), 125.3 (1C), 124.0 (1C), 123.6 (1C), 122.5 (1C), 118.4 (1C), 113.7 (1C), 60.1 (1C). IR (KBr film) $\left(\mathrm{cm}^{-1}\right) \vee 2924,2854,1800,1711,1604$, 1574, 1463, 1377, 814, 434. MS (ESI+) 396.3 [M + H]. HRMS (ESI+) calcd for $\mathrm{C}_{25} \mathrm{H}_{17} \mathrm{NNaO}_{4} 418.1050$; found $418.1046[\mathrm{M}+$ $\mathrm{Na}$.

\section{(3-(Chrysen-6-ylamino)-4-methoxycyclobut-3-ene-1,2-dione}

(5)

Following the general procedure using $1 \mathrm{~mL}$ of $\mathrm{MeOH}$ and $\mathrm{Et}_{3} \mathrm{~N}(0.2 \mathrm{mmol})$, compound 5 was obtained after $60 \mathrm{~h}$ of reaction at room temperature as a yellow paled solid in $76 \%$ yield (53.7 mg). M.p. $>260{ }^{\circ} \mathrm{C}$ Decomp. ${ }^{1} \mathrm{H}$ NMR (400 MHz, DMSO-d6) $\delta 11.20$ (br s, $1 \mathrm{H}), 9.00(\mathrm{~d}, J=8.0 \mathrm{~Hz}, 1 \mathrm{H}), 8.92$ (d, $J=8.1 \mathrm{~Hz}, 1 \mathrm{H}), 8.86(\mathrm{~d}, J=9.1 \mathrm{~Hz}, 1 \mathrm{H}), 8.69$ (br s, $1 \mathrm{H}), 8.32$ $(\mathrm{d}, J=7.6 \mathrm{~Hz}, 1 \mathrm{H}), 8.10(\mathrm{~d}, J=8.5 \mathrm{~Hz}, 2 \mathrm{H}), 7.88-7.59(\mathrm{~m}, 4 \mathrm{H})$, 4.34 (s, 3H). ${ }^{13} \mathrm{C}-\mathrm{APT}$ NMR (100 MHz, DMSO-d6) $\delta 188.7$ (1C), 184.9 (1C), 178.9 (1C), 170.8 (1C), 131.8 (1C), 131.7 (1C), 130.4 (1C), 129.8 (1C), 128.3 (1C), 127.4 (1C), 127.3 (1C), 127.1 (1C), 126.9 (1C), 126.8 (1C), 126.7 (1C), 126.5 (1C), 126.0 (1C), 123.7 (1C), 123.6 (1C), 123.4 (1C, 121.1 (1C), 116.0 (1C), 60.3 (1C). IR (KBr film) $\left(\mathrm{cm}^{-1}\right)$ v 3225, 2923, 2853, 1797, 1720, 1592, 1509, 1486, 1403, 809, 748, 447. MS (ESI+) $354.2[\mathrm{M}+\mathrm{H}]$. HRMS (ESI+) calcd for $\mathrm{C}_{23} \mathrm{H}_{15} \mathrm{NNaO}_{3}$ 376.0944; found $376.0934[\mathrm{M}+\mathrm{Na}]$.

\section{3-((9H-fluoren-2-yl)amino)-4-methoxycyclobut-3-ene-1,2- dione (6)}

Following the general procedure using $2 \mathrm{~mL}$ of $\mathrm{MeOH}$, compound 6 was obtained after $90 \mathrm{~min}$ of reaction at room temperature as a yellow solid in $77 \%$ yield (45 mg). M.p. $>250$ ${ }^{\circ} \mathrm{C}$ Decomp. ${ }^{1} \mathrm{H}$ NMR (400 MHz, DMSO-d6) $\delta 10.86$ (br s, $1 \mathrm{H}$ ), 7.89-7.83 (m, 2H), 7.61-7.54 (m, 2H), 7.42-7.34 (m, 2H), 7.32$7.26(\mathrm{~m}, 1 \mathrm{H}), 4.40(\mathrm{~s}, 3 \mathrm{H}), 3.92(\mathrm{~s}, 2 \mathrm{H}) .{ }^{13} \mathrm{C}-\mathrm{APT}$ NMR $(75$ $\left.\mathrm{MHz}, \mathrm{DMSO}-d_{6}\right) \delta 183.8$ (1C), 144.0 (1C), 142.7 (1C), 140.5 (1C), 137.2 (1C), 136.8 (1C), 126.9 (1C), 126.3 (1C), 124.9 (1C), 120.3 (1C), 119.6 (1C), 118.4 (1C), 116.3 (1C), 60.5 (1C), 36.4 (1C). IR (KBr film) $\left(\mathrm{cm}^{-1}\right)$ v 3245, 3198, 2923, 2853, 1795, 1709, 1606, 1584, 1522, 1519, 1467, 1389, 1077, 1016, 764, 730. MS (ESI+) 314.0 [M + Na]. HRMS (ESI+) calcd for $\mathrm{C}_{18} \mathrm{H}_{13} \mathrm{NNaO}_{3} 314.0788$; found 314.0781 [M $+\mathrm{Na}$ ].

\section{3-((9H-fluoren-2-yl)amino)-4-propoxycyclobut-3-ene-1,2- dione (7)}

Firstly, 3,4-dipropoxycyclobut-3-ene-1,2-dione was prepared with 3,4-dimethoxy-3-cyclobutene-1,2-dione at reflux in 1propanol during $24 \mathrm{~h}$. Following the general procedure and using the resulting squarate 3,4-dipropoxycyclobut-3-ene-1,2dione, compound 7 was obtained after $72 \mathrm{~h}$ of reaction at room temperature as a yellow solid in $68 \%$ yield $(43.7 \mathrm{mg})$. M.p. $>250{ }^{\circ} \mathrm{C}$ Decomp. ${ }^{1} \mathrm{H}$ NMR (400 MHz, DMSO- $\left.d_{6}\right) \delta 10.85$ (br $\mathrm{s}, 1 \mathrm{H}), 7.89-7.82(\mathrm{~m}, 2 \mathrm{H}), 7.62-7.54(\mathrm{~m}, 2 \mathrm{H}), 7.42-7.25(\mathrm{~m}$, $3 \mathrm{H})$, 4.75-4.68 (m, 2H), 3.92 (br s, 2H), 1.89-1.74 (m, 2H),
1.08-0.94 (m, 3H). ${ }^{13} \mathrm{C}-\mathrm{APT}$ NMR $\left(75 \mathrm{MHz}\right.$, DMSO- $\left.d_{6}\right) \delta$ 183.7 (1C), 169.2 (1C), 143.9 (1C), 142.7 (1C), 137.2 (1C), 136.8 (1C), 126.7 (1C), 126.3 (1C), 125.0 (1C), 120.3 (1C), 119.6 (1C), 118.5 (1C), 116.4 (1C), 74.6 (1C), 36.4 (1C), 22.8 (1C), 9.7 (1C). IR (KBr film) $\left(\mathrm{cm}^{-1}\right) \vee 3233,3122,3067,2923$, 2853, 1806, 1710, 1587, 1495, 1458, 1414, 1364, 828, 764, 727. MS (ESI+) 342.1 [M + Na]. HRMS (ESI+) calcd for $\mathrm{C}_{20} \mathrm{H}_{17} \mathrm{NNaO}_{3} 342.1101$; found 342.1090 [M $+\mathrm{Na}$.

3,4-bis((9H-fluoren-2-yl)amino)cyclobut-3-ene-1,2-dione (8) Following the general procedure using $2 \mathrm{~mL}$ of $\mathrm{MeOH}$ and $\mathrm{Et}_{3} \mathrm{~N}(0.2 \mathrm{mmol})$, compound 8 was obtained after $72 \mathrm{~h}$ of reaction at room temperature as a yellow solid in $23 \%$ yield (20 mg). M.p. $>250{ }^{\circ} \mathrm{C}$ Decomp. ${ }^{1} \mathrm{H}$ NMR (400 MHz, DMSO-d6) $\delta$ $10.01(\mathrm{~s}, 2 \mathrm{H}), 7.90(\mathrm{~d}, J=8.2 \mathrm{~Hz}, 2 \mathrm{H}), 7.85(\mathrm{~d}, J=7.4 \mathrm{~Hz}, 2 \mathrm{H})$, $7.78(\mathrm{~s}, 2 \mathrm{H}), 7.57(\mathrm{~d}, J=7.4 \mathrm{~Hz}, 2 \mathrm{H}), 7.49(\mathrm{dd}, J=8.2 \mathrm{~Hz}, J=$ $2.1 \mathrm{~Hz}, 2 \mathrm{H}), 7.41-7.35(\mathrm{~m}, 2 \mathrm{H}), 7.32-7.26(\mathrm{~m}, 2 \mathrm{H}), 2.08(\mathrm{~s}$, $4 \mathrm{H}) .{ }^{13} \mathrm{C}-\mathrm{DEPT}$ NMR (100 MHz, DMSO- $\left.d_{6}\right) \delta 126.5$ (2C), 126.1 (2C), 124.7 (2C), 120.1 (2C), 120.0 (2C), 119.4 (2C), 36.2 (2C). IR (KBr film) $\left(\mathrm{cm}^{-1}\right) \vee 3142,2923,2853,1786$, 1670, 1600, 1576, 1561, 1556, 1461, 1453, 952, 871, 819, 765, 730, 442. MS (ESI+) 441.2 [M + H]. HRMS (ESI-) calcd for $\mathrm{C}_{30} \mathrm{H}_{19} \mathrm{~N}_{2} \mathrm{O}_{2} 439.1452$; found 439.1456 [M - H].

Cell culture: HeLa (cervical cancer) cells were maintained in glucose DMEM (Dulbecco's Modified Eagle's Medium) supplemented with $5 \%$ fetal bovine serum (FBS), $200 \mathrm{U} / \mathrm{ml}$ penicillin, $100 \mu \mathrm{g} / \mathrm{ml}$ streptomycin and $2 \mathrm{mM} \mathrm{L-glutamine.}$ Cultures were maintained in a humidified atmosphere of $95 \%$ air $/ 5 \% \mathrm{CO}_{2}$ at $37^{\circ} \mathrm{C}$.

Cytotoxicity assay by MTT: The MTT assay was used to determine cell viability as an indicator for cells sensitivity to the complexes. Exponentially growing cells were seeded at a density of approximately $10^{4}$ cells/well in 96-well flatbottomed microplates and allowed to attach for $24 \mathrm{~h}$ prior to addition of compounds. The complexes were dissolved in DMSO and added to cells in concentrations ranging from 0.1 to $100 \mu \mathrm{M}$ in quadruplicate. Cells were incubated with our compounds for $24 \mathrm{~h}$ at $37{ }^{\circ} \mathrm{C}$. Ten microliters of MTT (5 $\mathrm{mg} / \mathrm{ml}$ ) were added to each well and plates were incubated for 2 $\mathrm{h}$ at $37^{\circ} \mathrm{C}$. Finally, plates were centrifuged for $10 \mathrm{~min}$ at $500 \mathrm{xg}$, media was eliminated and DMSO $(100 \mu \mathrm{l} /$ well $)$ was added to dissolve the formazan precipitates. The optical density was measured at $550 \mathrm{~nm}$ using a 96-well multiscanner autoreader (ELISA). The $\mathrm{IC}_{50}$ was calculated by non-linear regression analysis using Prism software (GraphPad Software Inc). Each compound was analysed at least in three independent experiments.

Human cell studies and cell fluorescence microscopy: HeLa cells were detached from the plastic flask using trypsin-EDTA solution and suspended in an excess volume of growth medium. The homogeneous cell suspension was then distributed into 30 $\mu \mathrm{l}$ aliquots in a 6 channel $\mu$-slide IV $^{0.4}$ (IBIDI), with each aliquot being subject to incubation with the different 
complexes, final concentrations ranged from $12.5 \mu \mathrm{M}$ to 50 $\mu \mathrm{M}$, at $37{ }^{\circ} \mathrm{C}$ for $12 \mathrm{~h}$. Then, $30 \mu \mathrm{l}$ of a solution $0.01 \mu \mathrm{M}$ the internal standard (LisoTracker Red DND-99) in cell growth medium was added to each well. Preparations were viewed using an Olympus FV10-i Oil type compact confocal laser microscope using a $\times 10$ or $\times 60$ objective, with excitation wavelength at 405,473 and $578 \mathrm{~nm}$.

\section{Acknowledgements}

Authors thank the Ministerio de Economía y Competitividad (MINECO/FEDER CTQ2013-48635-C2-1-P and SAF201348626-C2-2-R), and DGA-FSE (E77 and E104) for financial support of this research. J.V. A.-R. thanks to DGA for his predoctoral contract.

\section{Notes and references}

${ }^{a}$ Departamento de Química Inorgánica, Instituto de Síntesis Química y Catálisis Homogénea (ISQCH), Universidad de Zaragoza-CSIC, E-50009 Zaragoza, Spain. Phone: +34 976762291, Email: gimeno@unizar.es

${ }^{b}$ Departamento de Química Orgánica, Instituto de Síntesis Química y Catálisis Homogénea (ISQCH), Universidad de Zaragoza-CSIC, E-50009 Zaragoza, Spain. Phone: +34 976761190, Email: raquelph@unizar.es

c Departamento de Bioquímica y Biología Molecular y Celular, Universidad de Zaragoza, E-50009 Zaragoza, Spain.

Electronic Supplementary Information (ESI) available: ${ }^{1} \mathrm{H}$ and ${ }^{13} \mathrm{C}$ NMR spectra of all new products. See DOI: 10.1039/b000000x/

1 R. I. Storer, C. Aciro and L. H. Jones, Chem. Soc. Rev., 2011, 40, 2330.

2 a) J. Alemán, A. Parra, H. Jiang and K. A. Jørgensen, Chem.-Eur. J., 2011, 17, 6890; b) J. V. Alegre-Requena, Synlett, 2014, 25, 298; c) P. Chauhan, S. Mahajan, U. Kaya, D. Hack and D. Enders, Adv. Synth. Catal., 2015, 357, 253.

3 F. R. Wurm and H.-A. Klok, Chem. Soc. Rev., 2013, 42, 8220.

4 J. P. Malerich, K. Hagihara and V. H. Rawal, J. Am. Chem. Soc., 2008, 130, 14416.

5 a) B. Soberats, L. Martínez, E. Sanna, A. Sampedro, C. Rotger and A. Costa, Chem.-Eur. J., 2012, 18, 7533; b) C. López, E. Sanna, L. Carreras, M. Vega, C. Rotger and A. Costa, Chem. Asian J., 2013, 8, 84.

6 For scarce examples, see: a) C. Schieber, A. Bestetti, J. P. Lim, A. D. Ryan, T.-L. Nguyen, R. Eldridge, A. R. White, P. A. Gleeson, P. S. Donnelly, S. J. Williams and P. Mulvaney, Angew. Chem. Int. Ed., 2012, 51, 10523; b) A. Sampedro, R. Villalonga-Planells, M. Vega, G. Ramis, S. Fernández de Mattos, P. Villalonga, A. Costa and C. Rotger, Bioconjugate Chem., 2014, 25, 1537.

7 a) S. Tomás, M. C. Rotger, J. F. González, P. M. Deyà, P. Ballester and A. Costa, Tetrahedron Lett., 1995, 36, 2523; b) D. Quiñonero, A. Frontera, G. A. Suñer, J. Morey, A. Costa, P. Ballester and P. M. Deyà, Chem. Phys. Lett., 2000, 326, 247; c) S. Tomàs, R. Prohens, M. Vega, M. C. Rotger, P. M. Deyà, P. Ballester and A. Costa, J. Org. Chem., 1996, 61, 9394.

8 a) R. Prohens, S. Tomàs, J. Morey, P. M. Deyà, P. Ballester and A. Costa, Tetrahedron Lett., 1998, 39, 1063; b) D. Quiñonero, R. Prohens, C. Garau, A. Frontera, P. Ballester, A. Costa and P. M.
Deyà, Chem. Phys. Lett., 2002, 351, 115; c) C. Garau, A. Frontera, P. Ballester, D. Quiñonero, A. Costa and P. M. Deyà, Eur. J. Org. Chem., 2005, 179; d) A. Frontera, J. Morey, A. Oliver, M. N. Piña, D. Quiñonero, A. Costa, P. Ballester, P. M. Deyà and E. V. Anslyn, J. Org. Chem., 2006, 71, 7185.

9 a) A. Rostami, A. Colin, X. Y. Li, M. G. Chudzinski, A. J. Lough and M. S. Taylor, J. Org. Chem., 2010, 75, 3983; b) A. Rostami, C. J. Wei, G. Guérin and M. S. Taylor, Angew. Chem. Int. Ed., 2011, 50, 2059.

10 a) V. Amendola, G. Bergamaschi, M. Boiocchi, L. Fabbrizzi and M. Milani, Chem.-Eur. J., 2010, 16, 4368; b) V. Amendola, L. Fabbrizzi, L. Mosca and F.-P. Schmidtchen, Chem. -Eur. J., 2011, 17, 5972.

11 For recent examples, see also: a) C. E. Silva, H. F. Dos Santos, N. L. Speziali, R. Diniz and L. F. C. de Oliveira, J. Phys. Chem. A, 2010, 114, 10097; b) D. Quiñonero, K. A. López, P. M. Deyà, M. N. Piña and J. Morey, Eur. J. Org. Chem., 2011, 6187; c) G. Ambrosi, M. Formica, V. Fusi, L. Giorgi, E. Macedi, M. Micheloni, P. Paoli, R. Pontellini and P. Rossi, Chem.-Eur. J., 2011, 17, 1670; d) N. Busschaert, I. L. Kirby, S. Young, S. J. Coles, P. N. Horton, M. E. Light and P. A. Gale, Angew. Chem. Int. Ed., 2012, 51, 4426.

12 For recent selected examples, see: a) S. K. Narasimhan, P. Sejwal, S. Zhu and Y.-Y. Luk, Bioorg. Med. Chem., 2013, 21, 2210; b) X. Zhang, Z. Zuo, J. Tang, K. Wang, C. Wang, W. Chen, C. Li, W. Xu, X. Xiong, K. Yuntai, J. Huang, X. Lan and H.-B. Zhou, Bioorg. Med. Chem. Lett., 2013, 23, 3793; c) L.-Q. Deng, Y.-M. Lu, C.-Q. Zhou, J.-X. Chen, B. Wang and W.-H. Chen, Bioorg. Med. Chem. Lett., 2014, 24, 2859; d) F. Olmo, C. Rotger, I. Ramírez-Macías, L. Martínez, C. Marín, L. Carreras, K. Urbanová, M. Vega, G. ChavesLemaur, A. Sampedro, M. J. Rosales, M. Sánchez-Moreno and A. Costa, J. Med. Chem., 2014, 57, 987.

13 a) E. Marqués-López, J. V. Alegre-Requena and R. P. Herrera, European Pat. EP14382260.9 filed Jul. 07, 2014; b) J. V. AlegreRequena, E. Marqués-López and R. P. Herrera, RSC Adv., 2015, 5, 33450 .

14 T.-L. Wu, H.-H. Chou, P.-Y. Huang, C.-H. Cheng and R.-S. Liu, J. Org. Chem., 2014, 79, 267.

15 a) B. J. Smith, L. DeBruin, P. D. Josephy and T. E. Eling, Chem. Res. Toxicol., 1992, 5, 431; b) M.-D. Yang, S.-Y. Lin, T.-H. Chiu, C.-C. Lin, M.-L. Lin, S.-C. Hsu, C.-L. Kuo, M.-J. Sheu, C.-C. Wu, S.-S. Lin and J.-G. Chung, In vivo, 2008, 22, 729; c) N. Asare, M. Låg, D. Lagadic-Gossmann, M. Rissel, P. Schwarze and J. A. Holme, Toxicology, 2009, 255, 140.

16 V. Fernández-Moreira, I. Marzo and M. C. Gimeno, Chem. Sci., 2014, 5, 4434.

17 J. R. Casey, S. Grinstein and J. Orlowski, Nat. Rev. Mol. Cell Biol., 2010, 11, 50.

18 S. Hainke and O. Seitz, Angew. Chem. Int. Ed., 2009, 48, 8250.

19 R. Corradini, S. Sforza, T. Tedeschi and R. Marchelli, Chirality, 2007, 19, 269. 